\section{Prognose ved epilepsi hos barn}

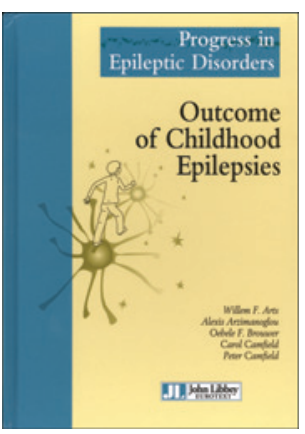

Willem F. Arts, Alexis Arzimanoglou,

Oebele F. Brouwer et al. Outcome of childhood epilepsies

261 s, tab, ill. Montrouge: John Libbey eurotext, 2013. Pris EUR 81

ISBN 978-2-7420-1102-5

Denne boken er basert på en workshop som ble arrangert i Den Haag i Nederland i 2012. Her deltok en rekke av de mest toneangivende innen barneepileptologien, og disse finnes da også igjen i forfatterlisten.

Foranledningen til møtet var 25-årsmarkeringen av den kjente nederlandske barneepilepsistudien The Dutch Study of Epilepsy in childhood (DSEC). Studien omfatter nesten 500 barn som ble rekruttert fra fire hollandske sykehus og fulgt opp systematisk fra 1987. Hensikten med møtet var å drøfte resultatene fra denne studien og definere nye forskningsspørsmål. Noen utvalgte deltakere ble invitert til å skrive hvert sitt kapittel.

Boken er ment å gi en state-of-the-art-oversikt over noen sentrale temaer innen barneepileptologien. Målgruppen er først og fremst pediatere med særlig interesse for epilepsi, men den kan også leses med utbytte av generelle pediatere og nevrologer.

Denne inngår i en samling bøker utgitt av tidsskriftet Epileptic Disorders under tittelen Progress in Epileptic Disorders. Målet har vært å samle det siste innen epilepsiforskning ved å arrangere workshops, for raskt etter møtene å utgi bøker.

Dette er ingen systematisk gjennomgang av alle aspekter ved epilepsi hos barn. Men den gir svar på enkelte relevante kliniske spørsmål. Eksempelvis drøftes i første kapittel muligheten for å enes om de samme inklusjonskriteriene og endemålene for studier innen dette feltet, noe som gjør det mulig å sammenlikne resultatene. Basert på tilgjengelig litteratur diskuteres hvordan man best kan estimere prognosen etter et første uprovosert anfall, ved nydiagnostisert epilepsi og ved forskjellige epilepsisyndromer. Imponerende lange referanselister vitner om en grundig litteraturgjennomgang.

For meg fremstår verket som et kompendium. Ingen bilder samt lite figurer og tabeller gjør layouten litt kjedelig. Det er allerede mer enn to år siden workshopen ble arrangert. Mange av studiene som det refereres til, er av eldre dato. Lesere som jakter på «ferskvare» innen dette feltet (hvem gjør ikke det?), vil nok ha større utbytte av å lese de nyeste originalartikler, systematiske oversiktsartikler eller metaanalyser fremfor å kjøpe denne boken.

\section{Anette Ramm-Pettersen}

Overlege, Seksjon for barn og unge med epilepsi Oslo universitetssykehus

\section{Depresjon som verdens midtpunkt}

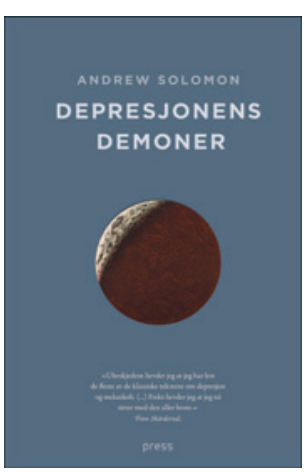

Andrew Solomon

Depresjonens demoner

601 s. Oslo: Forlaget Press, 2014

Pris NOK 199

ISBN 978-82-7547-660-7

Forfatteren av denne voluminøse populærvitenskapelige boken har selv en bipolar lidelse og har vært gjennom flere store «sammenbrudd» og flere typer psykoterapi og biologiske behandlingsmetoder. Motivene for å skrive denne er folkeopplysning og hjelp til selvhjelp samt i noen grad å vise hvordan den depressive lidelsen og personligheten spiller sammen. Dette er ingen deprimerende bok, for utvalget av intervjuede personer med forskjellige typer depresjon er alle bemerkelsesverdige mennesker med suksesshistorier. Men de er dermed lite representative.

Dette er resultatet av forfatterens omfattende research i fag- og skjønnlitteratur, tre egne depressive sammenbrudd som beskrives detaljert, og intervjuer med vellykkede pasienter og sentrale psykiatere og kliniske psykologer i USA. Den er nesten for omfattende til å leses fra perm til perm, men de enkelte kapitlene kan leses uavhengig av hverandre. Fire kapitler omhandler depresjon, sammenbrudd, rusmiddelavhengighet og selvmord - der hans egen historie står sentralt for å belyse depresjonen i et fenomenologisk perspektiv. I ett kapittel gjennomgår han ulike psykiatriske behandlingsmetoder, i et annet alle mulige alternative hjelpemåter som finnes. Depresjonsbegrepets historie, sammenhenger mellom depresjon og fattigdom, helsepolitikken i USA og depresjon samt evolusjonsperspektivet på depresjon gjennomgås også i ganske stor detalj. Siste kapittel heter Håp, og her er budskapet at man ikke må la depresjonen stjele uker, måneder og år av ens liv, men søke tidlig hjelp og arbeide med den selv også.

Er det en bok å anbefale pasienter? Jeg vil nøle med det. Dels er den for omfattende, tar med likt og ulikt, skiller ikke mellom hva som er personlighetsproblematikk og hva som har med depresjonslidelsen å gjøre og forklarer dermed «alt» ut fra at personen er depressiv. Dels er også behandlinger som refereres preget av amerikansk multifarmakologi med opptil 11 medikamenter til én pasient, og av en typisk amerikansk splitt mellom «psykiateren min», «psykofarmakologen min» og «psykoterapeuten min». For en deprimert pasient eller en pårørende kan kapitlene om behandling og alternativ behandling virke kaotiske når alt fremstilles som like bra eller like dårlig, uten angivelse av indikasjoner og kontraindikasjoner.

Er det en bok for leger? Kanskje for noen som vil ha en omfattende, men populærvitenskapelig oversikt over hvordan det oppleves å være deprimert og hvordan depresjon preger liv og samfunn.

Per Vaglum

Professor emeritus, Avdeling for medisinsk atferdsvitenskap

Universitetet i Oslo 